\title{
Impact of tembotrione and flufenacet plus isoxaflutole application timings, rates, and adjuvant type on weeds and yield of maize
}

\author{
Robert Idziak $^{1^{*}}$, and Zenon Woznica ${ }^{1}$
}

\begin{abstract}
Due to the steadily increasing cost of weed control in corn (Zea mays L.) and possible negative impact of chemicals on environment the demand for less and more efficient herbicide use is rising. Field studies were carried out in 2010 and 2011 in the Middle-West Poland in order to assessment the effective weed control. Treatments included herbicides tembotrione and flufenacet + isoxaflutole at recommended $\left(88.0\right.$ and $\left.36.0+7.5 \mathrm{~g} \mathrm{ha}^{-1}\right)$ and reduced rates $\left(44\right.$ and $22 \mathrm{~g} \mathrm{ha}^{-1} ; 19.2+4.0$ or $9.6+2.0 \mathrm{~g} \mathrm{ha}^{-1}$ ) with addition of methylated seed oil (MSO) and ammonium nitrate (AMN) adjuvants. Tembotrione was applied once at the stage of 3-5 maize leaves and flufenacet + isoxaflutole once at pre-emergence of maize. Mixtures of these herbicides were applied sequentially post-emergence, at 16-20-d intervals, after successive weed emergence. Results indicate that herbicide applied at reduced rates with adjuvants provided satisfactory weed control in maize. Application of reduced rates of tembotrione (44 and $22 \mathrm{~g} \mathrm{ha}^{-1}$ ) and especially mixture of tembotrione with flufenacet + isoxaflutole and MSO + AMN adjuvants applied twice provided similar grain yield of maize as from treatments where tembotrione or flufenacet + isoxaflutole herbicides were applied only once at recommended rates $\left(9.5,9.7\right.$, and $10.0 \mathrm{t} \mathrm{ha}^{-1}$, respectively).
\end{abstract}

Key words: Adjuvant, weed control, Zea mays.

\section{INTRODUCTION}

Maize (Zea mays L.) is one of the most popular crops in Poland grown for human and animal consumption. Weeds cause huge losses due to their competition with crops (Naeem et al., 2012). Maize is very sensitive to weed infestation that usually causes severe yield reduction especially in dryland conditions (Sulewska et al., 2012; Idziak and Woznica 2013). According to Isik et al. (2006) weeds occurrence in maize causes significant yield losses with an average of more than $29 \%$ in case of no weed control and more than $12 \%$ despite weed control applications. Critical period for weed control depends on the density, competitiveness and emergence periodicity of the weed population (Evans et al., 2003; Bystro et al., 2012). In maize this period varied from 1 to 15 -leaf stages of crop (Ghanizadeh et al., 2010). Thus, weed control in maize is absolutely necessary and is mainly based on chemical method.

Currently herbicides available for post-emergence weed control in maize have relatively short time of action, and most of them are recommended in Poland only for single application during the maize growing season. In

${ }^{1}$ Poznań University of Life Sciences, Faculty of Agronomy and Bioengineering, Wojska Polskiego 28, 60-637 Poznań, Poland. "Corresponding author (robertid@up.poznan.pl).

Received: 22 October 2013.

Accepted: 12 March 2014.

doi:10.4067/S0718-58392014000200001 many cases, the primary, well weed controlled plantation is exposed to the emergence of a secondary infestation. Thus, the effectiveness of post-emergence-applied herbicides is not always satisfactory, and competition from remaining weeds can result in significant yield losses (Vahedi et al., 2013). The use of herbicide mixtures applied at least twice at terms when weeds are the most sensitive can be a good solution and bring notable benefits, as in the sugar beet (Woznica and Idziak, 2010) or cereals (Ramsdale and Messersmith, 2002).

Chemical weed control has some disadvantages or side effects and one of them is increased production costs. Intensive use of herbicides is associated with soil and water pollution and additionally with selection of herbicide resistant weed biotypes (Price et al., 2011). To reduce the cost of intensive herbicide application, environment pollution and enhance biological effectiveness, methods of weed control should be optimized. The aim of this study was to work up and test in the field the effectiveness of one or more herbicides covering a broad spectrum of weeds, applied in maize once or twice with methylated seed oil and ammonium nitrate adjuvant mixture.

\section{MATERIAL AND METHODS}

Field studies were carried out in 2010 and 2011 at Poznan University of Life Sciences Research and Education Center in Brody $\left(52^{\circ} 25^{\prime} \mathrm{N}, 016^{\circ} 18^{\prime} \mathrm{E}\right)$, Poland. The soil at the site is Luvisols (SgP, 2011). Soil texture was a sandy loam containing $1.2 \%$ to $1.4 \%$ organic matter, 
and $\mathrm{pH}$ ranged between 6.4 and 6.6. Plots measured 5.0 $\mathrm{m}$ in length by four rows wide $(2.5 \mathrm{~m})$. Tillage included moldboard plowing in the fall and shallow surface cultivation in spring. Mineral fertilizers were applied according to the local recommendations and plant needs, taking into account the nutrient content in the soil. Fertilizer consisting of $60 \mathrm{~kg} \mathrm{ha}^{-1}$ of $\mathrm{P}$ and $\mathrm{K}$ were applied prior to plowing in the fall. Fields received $80 \mathrm{~kg} \mathrm{~N}^{-1}$ before planting and $60 \mathrm{~kg} \mathrm{~N}^{-1}$ at 2 to 3 leaf stage of maize. Maize varieties P8000 in 2010, and P8100 in 2011, were planted at rate of 80000 grains ha-1 on 26 April in both years.

Experiment was arranged in a randomized complete block design with four replicates. Treatments included herbicides tembotrione (2-\{2-chloro-4-mesyl-3-[(2,2,2trifluoroethoxy)methyl] benzoyl $\}$ cyclohexane-1,3-dione, Laudis 44 OD, Bayer CropScience, Monheim, Germany) at 88,44 , and $22 \mathrm{~g} \mathrm{ha}^{-1}$ and flufenacet (4'-fluoro- $N$ isopropyl-2-[5-(trifluoromethyl)-1,3,4-thiadiazol-2yloxy]acetanilide) + isoxaflutole (5-cyclopropyl-1,2oxazol-4-yl)( $\alpha, \alpha, \alpha$-trifluoro-2-mesyl-p-tolyl)methanone, Boreal 58 WG, Bayer CropScience, Monheim, Germany) at $36+7.5,19.2+4$, and $9.6+2 \mathrm{~g} \mathrm{ha}^{-1}$ with addition of emulsified methylated seed oil (MSO, Atpolan BIO 80 EC, ZPH Agromix, Niepolomice, Poland) at 1 L $\mathrm{ha}^{-1}$, based on rapeseed oil fatty acids with a build-in surfactant buffering $\mathrm{pH}$ of the liquid spray liquid at the level of 7.3-7.8, and ammonium nitrate $(30 \%$ N, Grupa Azoty, Tarnow, Poland). Tembotrione was applied once at recommended rate of $88 \mathrm{~g} \mathrm{ha}^{-1}$ and reduced rates of 44 and $22 \mathrm{~g} \mathrm{ha}^{-1}$, and flufenacet + isoxaflutole at recommended rate of $36+7.5 \mathrm{~g} \mathrm{ha}^{-1}$ and reduced rate of $19.2+4$ or 9.6 $+2 \mathrm{~g} \mathrm{ha}^{-1}$. The adjuvant MSO was applied at $1.0 \mathrm{~L} \mathrm{ha}^{-1}$ and ammonium nitrate at $2.0 \mathrm{~kg} \mathrm{ha}^{-1}$. Tembotrione was applied once (A) at recommended and reduced rates at the stage of 3-5 maize unfolded leaves (BBCH 13-15), and flufenacet + isoxaflutole at recommended rate was applied once before emergence of maize $(0)-\mathrm{BBCH} 00$ (BBCH scale, Biologische Bundesanstalt, Bundessortenamt and Chemical industry; Meier, 2001). Mixtures of tembotrione with adjuvants or tembotrione + flufenacet + isoxaflutole + adjuvants were applied once (A) and twice post-emergence, at 16-20-d intervals, after successive weed emergence (BC). An untreated control was included. Treatments were applied with $\mathrm{CO}_{2}$-pressurized sprayer equipped with Lurmark 02110 nozzles calibrated to deliver $230 \mathrm{~L} \mathrm{ha}^{-1}$ at $0.22 \mathrm{MPa}$. Treatment dates and environmental conditions at the time of treatment are given in Table 1. Chenopodium album L., Viola arvensis Murray, and volunteer Brassica napus L. control were assessed 6 wk after post-emergence treatment by estimating reduction in weed fresh mass from herbicide treatment compared to untreated control. Assessment of herbicidal efficacy was based on the Henderson-Tilton formula (Bailey et al., 2013). Visible injury of maize on a scale ranging from 0 (no injury) to $100 \%$ (complete plant
Table 1. Meteorological data at Research and Education Center Brody during spray application.

\begin{tabular}{lccccc}
\hline $\begin{array}{l}\text { Treatment } \\
\text { date }\end{array}$ & Timing $^{1}$ & Temperature & $\begin{array}{c}\text { Relative } \\
\text { humidity }\end{array}$ & Wind & $\begin{array}{c}\text { Cloud } \\
\text { cover }\end{array}$ \\
\hline & & ${ }^{\circ} \mathrm{C}$ & $\%$ & $\mathrm{~m} \mathrm{~s}^{-1}$ & $\%$ \\
26 April 2010 & 0 & 19.3 & 53 & 0.9 & 0 \\
20 May 2010 & $\mathrm{B}$ & 13.2 & 70 & 0.0 & 60 \\
25 May 2010 & $\mathrm{A}$ & 14.9 & 54 & 1.4 & 60 \\
17 June 2010 & $\mathrm{C}$ & 17.5 & 54 & 1.4 & 0 \\
27 April 2011 & 0 & 16.0 & 62 & 1.2 & 10 \\
16 May 2011 & $\mathrm{B}$ & 17.1 & 41 & 1.3 & 90 \\
23 May 2011 & $\mathrm{A}$ & 11.0 & 68 & 0.0 & 40 \\
2 June 2011 & $\mathrm{C}$ & 17.7 & 57 & 0.0 & 10 \\
\hline
\end{tabular}

${ }^{1} 0$ : Maize BBCH 00 (dry seed); A: maize BBCH 13-15 (3-5 unfolded leaves); B: maize BBCH 12-13 (3-3 unfolded leaves); C: maize BBCH 16-18 (6-8 unfolded leaves).

The adjuvant MSO was applied at $1.0 \mathrm{~L} \mathrm{ha}^{-1}$ and ammonium nitrate at 2.0 $\mathrm{kg} \mathrm{ha}^{-1}$. Tembotrione was applied once (A) at recommended and reduced rates at the stage of 3-5 maize leaves (BBCH 13-15), and flufenacet + isoxaflutole at recommended rate was applied once before emergence of maize $(0)-\mathrm{BBCH}$ 00. Mixtures of tembotrione with adjuvants or tembotrione + flufenacet + isoxaflutole + adjuvants were applied once (A) and twice post-emergence, at 16-20-d intervals, after successive weed emergence (BC). An untreated control was included.

death), and chlorophyll content in maize leaves (SPAD test, Soil and Plant Analysis Development) was assessed 14 and $28 \mathrm{~d}$ after application. A chlorophyll meter ( $\mathrm{N}$ tester, Yara International ASA, Oslo, Norway) was used to record the chlorophyll content (SPAD value). Thirty plants were selected at random per plot, and a second leaf from the top of each plant was selected to recording the SPAD values. Maize grain yield was determined by harvesting the two centre rows of each plot, and grain yield was expressed at $15 \%$ moisture content.

All statistical procedures were conducted using ARM 8 software (Agricultural Research Manager, Gylling Data Management, Inc., Brookings, South Dakota, USA). The variances were partitioned into the fixed effects of herbicide treatment and into the random effects of year. Protected Tukey's least significance difference was used to separate treatment means $(\mathrm{P}=0.05)$. Percent rating of weed control were arc-sine transformed prior to analysis to correct for unequal variance. Data in tables are reported as non-transformed. The random effects of treatment, year, and their interactions were not significant; therefore data were pooled only by treatment.

\section{RESULTS AND DISCUSSION}

Activity of foliar herbicide sprays can be influenced by the environmental conditions at the time of spraying (Ramsey, 2003; Lubbers et al., 2007; Idziak and Woznica, 2009). Effectiveness of herbicides is also strongly modified by biological properties of the target weeds and spray liquid properties. These factors lead to a low stability of herbicides in variable conditions, as well as make it possible phytotoxic to the crop (Golebiowska and Rola, 2003). Generally, high temperature or high humidity may stimulate herbicide action. Temperature affects herbicide solubility, volatility, sorption, desorption and, finally 
herbicide activity. Temperature increase from 10 to 30 ${ }^{\circ} \mathrm{C}$ enhances the phytotoxicity of herbicide by increasing the absorption and translocation of active ingredients in a plant (Mphundi and Allemann, 2010). Ramsey et al. (2005) claimed that evaporation of herbicide from a plant surface is slower under high humidity conditions and its increases herbicide performance. During the present study meteorological conditions in both years rather favored the action of herbicides, especially those applied post-emergence in mixtures and with adding adjuvants.

Weed flora of experimental fields consisted of eighteen species of broad-leaved weeds and three species of grasses. The major broad leaved weeds were Ch. album, $V$. arvensis, and volunteer B. napus. Among the grassy weeds Echinochloa crus-galli (L.) P. Beauv., Setaria viridis (L.) P. Beauv., and Elymus repens (L.) Gould were noticed.

According to Matuszkiewicz (2012), in Poland the commonest weed community in maize fields is PolygonoChenopodietalia community with Ch. album and E. crus-galli and other species, mainly Polygonum ssp., Solanum nigrum L., Amaranthus retroflexus L., and Anthemis arvensis L. (Tański and Idziak, 2009; Kierzek et al., 2011). According to Dewey and Andersen (2004) knowledge about weed community structure is critical for planning effective weed management system.

There were significant differences among treatments in herbicidal efficacy on presented weed species based on their biomass reduction (Table 2). Tembotrione at 44 or $22 \mathrm{~g} \mathrm{ha}^{-1}$ with $\mathrm{MSO}+\mathrm{AMN}$ adjuvants, and with flufenacet + isoxaflutole herbicide mixture applied once or twice controlled Ch. album as effective as tembotrione applied singly at recommended rate of $88 \mathrm{~g} \mathrm{ha}^{-1}$. At the same time control of Ch. album with flufenacet + isoxaflutole was poorer. Tembotrione mixtures with flufenacet + isoxaflutole and MSO + AMN adjuvants applied once and tembotrione alone at $44 \mathrm{~g} \mathrm{ha}^{-1}$ with $\mathrm{MSO}+\mathrm{AMN}$ and at
$22 \mathrm{~g} \mathrm{ha}^{-1}$ with flufenacet + isoxaflutole and MSO + AMN applied twice reduced biomass of $V$. arvensis greater than tembotrione at each rate applied only once, regardless of adjuvants used, and flufenacet + isoxaflutole applied singly or tembotrione at $22 \mathrm{~g} \mathrm{ha}^{-1}$ with $\mathrm{MSO}+\mathrm{AMN}$ applied twice. With regard to $B$. napus excellent control was achieved with tembotrione at 88 and $44 \mathrm{~g} \mathrm{ha}^{-1}$ and at reduced rates with $\mathrm{MSO}+\mathrm{AMN}$ adjuvants, and also with flufenacet + isoxaflutole. Tembotrione with MSO + AMN at reduced rates and in mixture with flufenacet + isoxaflutole applied twice controlled B.napus even slightly greater. Tembotrione rate had significant impact on the total weed biomass reduction. The reduced tembotrione rates of 44 and $22 \mathrm{~g} \mathrm{ha}^{-1}$ applied singly gave significantly lower efficacy. However, substantial increase of efficacy of tembotrione at $44 \mathrm{~g} \mathrm{ha}^{-1}$ was associated with addition of $\mathrm{MSO}+\mathrm{AMN}$ adjuvants or additionally with application of these herbicides with flufenacet + isoxaflutole. MSO and AMN adjuvants increased efficacy of tembotrione at 44 and $22 \mathrm{~g} \mathrm{ha}^{-1}$ and its mixture with flufenacet + isoxaflutole when applied twice.

The right time of post-emergence herbicide application influence effectiveness of weed control in maize. Too early and too late application suffer reduced efficacy (Williams and Harvey, 2000). An important component of weed management is therefore the determination of critical period for weed control, when weed interference results in unacceptable yield losses (Keller et al., 2012). Single herbicides do not always control weeds economically and completely (Woznica and Idziak, 2010). Choice of two or more active ingredients for weed control generally increases herbicide efficacy. This is due to the increase the range of the target weed species, and sometimes also to a synergistic interaction between herbicides. Additionally, using mixtures of herbicides with different modes of action slowdown selection of herbicide-resistant biotypes

Table 2. Effect of herbicide, time of application, and adjuvants on weed biomass reduction.

\begin{tabular}{|c|c|c|c|c|c|c|c|}
\hline \multirow[b]{3}{*}{ Treatment } & \multirow[b]{3}{*}{ Rate } & \multirow[b]{3}{*}{ Adjuvant $^{1}$} & \multirow[b]{3}{*}{$\begin{array}{c}\text { Time of } \\
\text { application }\end{array}$} & \multicolumn{4}{|c|}{ Weed species } \\
\hline & & & & $\begin{array}{c}\text { Chenopodium } \\
\text { album }\end{array}$ & $\begin{array}{c}\text { Viola } \\
\text { arvensis }\end{array}$ & $\begin{array}{l}\text { Brassica } \\
\text { napus }\end{array}$ & Total $^{3}$ \\
\hline & & & & \multicolumn{4}{|c|}{ Weed biomass reduction $(\%)^{4}$} \\
\hline & g ai ha ${ }^{-1}$ & & & $\mathrm{~g} \mathrm{~m}^{-2}$ & & & \\
\hline Untreated control & - & - & - & 1092 & 46 & 1342 & 2894 \\
\hline Tembotrione & 88 & None & $\mathrm{A}$ & $99 a$ & $72 \mathrm{c}$ & $98 \mathrm{a}$ & $91 \mathrm{a}$ \\
\hline Tembotrione & 44 & None & A & $95 \mathrm{ab}$ & $61 \mathrm{c}$ & $93 a$ & $75 b c$ \\
\hline Tembotrione & 22 & None & A & $85 b$ & $59 \mathrm{c}$ & $62 \mathrm{c}$ & $49 \mathrm{e}$ \\
\hline Tembotrione & 44 & MSO+AMN & $\mathrm{A}$ & $96 a b$ & $64 c$ & $97 \mathrm{a}$ & $85 \mathrm{ab}$ \\
\hline Tembotrione & 22 & $\mathrm{MSO}+\mathrm{AMN}$ & $\mathrm{A}$ & $94 \mathrm{ab}$ & $64 c$ & $78 b$ & $71 \mathrm{~cd}$ \\
\hline Flufenacet + isoxaflutole & $36+7.5$ & None & 0 & $67 \mathrm{c}$ & $72 \mathrm{c}$ & $95 \mathrm{a}$ & $62 d$ \\
\hline Tembotrione + flufenacet + isoxaflutole & $44+19.2+4.0$ & $\mathrm{MSO}+\mathrm{AMN}$ & $\mathrm{A}$ & $96 \mathrm{ab}$ & $100 \mathrm{a}$ & $86 a b$ & $85 \mathrm{ab}$ \\
\hline Tembotrione & 44 & $\mathrm{MSO}+\mathrm{AMN}$ & $\mathrm{B} / \mathrm{C}$ & $100 \mathrm{a}$ & $95 \mathrm{ab}$ & $100 \mathrm{a}$ & $92 \mathrm{a}$ \\
\hline Tembotrione & 22 & $\mathrm{MSO}+\mathrm{AMN}$ & $\mathrm{B} / \mathrm{C}$ & $99 \mathrm{a}$ & $75 b c$ & $99 \mathrm{a}$ & $87 \mathrm{ab}$ \\
\hline Tembotrione + flufenacet + isoxaflutole & $22+9.6+2.0$ & $\mathrm{MSO}+\mathrm{AMN}$ & $\mathrm{B} / \mathrm{C}$ & $100 \mathrm{a}$ & $95 \mathrm{ab}$ & $100 \mathrm{a}$ & $96 a$ \\
\hline
\end{tabular}

Means within a columns followed by the same letter are not significantly different according to Tukey's test (P $\leq 0.05)$.

${ }^{1} \mathrm{MSO}$ : Methylated seed oil at $1.0 \mathrm{~L} \mathrm{ha}^{-1}$; AMN: ammonium nitrate at $2.0 \mathrm{~kg} \mathrm{ha}^{-1}$.

${ }^{2} 0$ : Maize BBCH 00 (dry seed); A: maize BBCH 13-15 (3-5 unfolded leaves); B: maize BBCH 12-13 (3-3 unfolded leaves); C: maize BBCH 16-18 (6-8 unfolded leaves).

${ }^{3}$ Based on all weed species occurring during field studies.

${ }^{4}$ Weed data for statistical analyses were arcsin transformed to stabilize variances but original values are presented. 
(Zollinger, 2011). Tembotrione used alone or in mixture with flufenacet + isoxaflutole effectively controlled weeds, especially when applied twice (Gatzweiler et al., 2012). Based on our studies it can be concluded that the addition of adjuvants to the spray liquid was due to increased retention of the spray droplets on the weed leaves surface and also increased rate of absorption of the herbicide into the target plant (Costa et al., 2005). Adjuvant MSO plus fertilizer origin adjuvants (AMN, UAN) are typically applied with HPPD-inhibitor herbicides (tembotrione or mesotrione), and substantially improve weed control (Young et al., 2007).

Our results indicate that the mixture of tembotrione $\left(44 \mathrm{~g} \mathrm{ha}^{-1}\right)+$ flufenacet $\left(19.2 \mathrm{~g} \mathrm{ha}^{-1}\right)+$ isoxaflutole (4 $\mathrm{g} \mathrm{ha}^{-1}$ ) with MSO + AMN adjuvants applied once and tembotrione $\left(22 \mathrm{~g} \mathrm{ha}^{-1}\right)+$ flufenacet $\left(9.6 \mathrm{~g} \mathrm{ha}^{-1}\right)+$ isoxaflutole $\left(2 \mathrm{~g} \mathrm{ha}^{-1}\right)$ with $\mathrm{MSO}+\mathrm{AMN}$ applied twice were phytotoxic to maize plants, causing $39 \%$ and $46 \%$ injury $14 \mathrm{~d}$ after treatment (DAT) and $20 \%$ and $21 \%$ injury 28 DAT, respectively (Table 3). However, plant injuries were not observed after further $14 \mathrm{~d}$. The other herbicide treatments were safe for maize plant. SPAD test indicate that chlorophyll content in maize leaves ranged from 513 to 535 (14 DAT) and from 504 to 526 (28 DAT) on not injured treatments (Table 3). However, SPAD values were lower when plant injury were observed and ranged from 477 to 505 (treatment 7) and from 407 to 446 (treatment 10). The chlorophyll content in plant leaves is related to the condition of the plant. Studies conducted by Armel et al. (2003) indicate temporary plant injury after application of HPPD-inhibitor in the form of bleached leaves and stunted plants but injury was transient and did not reduce maize or sorghum yields (Armel et al., 2003; Idziak et al., 2013). According to Snarska and Konecki (2010) mixture of flufenacet + isoxaflutole applied in sorghum caused severe injury of plants, but Waligora et al. (2008a) indicate good selectivity or only transient injury of these herbicides for maize plants (Waligora et al., 2008b).

Recorded data indicate that maize grain yield from treatment ranged from 7.8 to $10.9 \mathrm{t} \mathrm{ha}^{-1}$ (Table 4). The highest yield was from treatments where tembotrione was applied once at $88 \mathrm{~g} \mathrm{ha}^{-1}$, and the lowest yield maize (except untreated plots) were obtained where the tembotrione was applied once at $22 \mathrm{~g} \mathrm{ha}^{-1}$. Reduction of tembotrione rate applied without adjuvants decreased maize grain yield by $10-23 \%$ as compared to recommended rate. However, addition of MSO and AMN adjuvants to tembotrione applied once at $44 \mathrm{~g} \mathrm{ha}^{-1}$ caused an increase in yield by

Table 3. Effect of herbicide, time of application and adjuvants on maize plant injury and chlorophyll content in leaves.

\begin{tabular}{|c|c|c|c|c|c|c|c|}
\hline \multirow[b]{2}{*}{ Treatment } & \multirow[b]{2}{*}{ Rate } & \multirow[b]{2}{*}{ Adjuvant $^{1}$} & \multirow{2}{*}{$\begin{array}{c}\text { Time of } \\
\text { application }^{2}\end{array}$} & \multicolumn{2}{|c|}{ Plant injury } & \multicolumn{2}{|c|}{ SPAD test } \\
\hline & & & & $14 \mathrm{DAT}^{3}$ & 28 DAT & $14 \mathrm{DAT}^{3}$ & 28 DAT \\
\hline & g ai ha ${ }^{-1}$ & & & + & + & & \\
\hline Untreated control & - & - & - & $0 \mathrm{c}$ & $\mathrm{Ob}$ & $536 \mathrm{a}$ & $516 a$ \\
\hline Tembotrione & 88 & None & A & $0 \mathrm{c}$ & $0 b$ & $524 a$ & $525 \mathrm{a}$ \\
\hline Tembotrione & 44 & None & A & $0 \mathrm{c}$ & $0 b$ & $525 \mathrm{a}$ & $526 a$ \\
\hline Tembotrione & 22 & None & $\mathrm{A}$ & $0 \mathrm{c}$ & $\mathrm{Ob}$ & $516 a$ & $520 \mathrm{a}$ \\
\hline Tembotrione & 44 & $\mathrm{MSO}+\mathrm{AMN}$ & $\mathrm{A}$ & $0 \mathrm{c}$ & $0 b$ & $513 a$ & $515 a$ \\
\hline Tembotrione & 22 & $\mathrm{MSO}+\mathrm{AMN}$ & $\mathrm{A}$ & $0 \mathrm{c}$ & $\mathrm{Ob}$ & $516 a$ & $523 a$ \\
\hline Flufenacet + isoxaflutole & $36+7.5$ & None & 0 & $0 \mathrm{c}$ & $0 b$ & $520 \mathrm{a}$ & $504 \mathrm{a}$ \\
\hline Tembotrione + flufenacet + isoxaflutole & $44+19.2+4.0$ & MSO+AMN & A & $39 b$ & $20 \mathrm{a}$ & $477 \mathrm{~b}$ & $505 \mathrm{a}$ \\
\hline Tembotrione & 44 & $\mathrm{MSO}+\mathrm{AMN}$ & $\mathrm{B} / \mathrm{C}$ & $0 \mathrm{c}$ & $0 \mathrm{~b}$ & $519 \mathrm{a}$ & $512 \mathrm{a}$ \\
\hline Tembotrione & 22 & $\mathrm{MSO}+\mathrm{AMN}$ & $\mathrm{B} / \mathrm{C}$ & $0 \mathrm{c}$ & $\mathrm{Ob}$ & $515 a$ & $519 \mathrm{a}$ \\
\hline Tembotrione + flufenacet + isoxaflutole & $22+9.6+2.0$ & $\mathrm{MSO}+\mathrm{AMN}$ & $\mathrm{B} / \mathrm{C}$ & $46 a$ & $21 \mathrm{a}$ & $407 \mathrm{c}$ & $446 \mathrm{c}$ \\
\hline
\end{tabular}

${ }^{1}$ MSO: Methylated seed oil at $1.0 \mathrm{~L} \mathrm{ha}^{-1}$; AMN: ammonium nitrate at $2.0 \mathrm{~kg} \mathrm{ha}^{-1}$.

20: Maize BBCH 00 (dry seed); A: maize BBCH 13-15 (3-5 unfolded leaves); B: maize BBCH 12-13 (3-3 unfolded leaves); C: maize BBCH 16-18 (6-8 unfolded leaves).

${ }^{3}$ DAT: days after treatment.

Means within a columns followed by the same letter are not significantly different according to Tukey's test (P $\leq 0.05$ ).

Table 4. Effect of herbicide, time of application and adjuvants on maize grain yield.

\begin{tabular}{|c|c|c|c|c|c|}
\hline \multirow[t]{2}{*}{ Treatment } & \multirow{2}{*}{$\frac{\text { Rate }}{\text { g ai ha }{ }^{-1}}$} & \multirow[t]{2}{*}{ Adjuvant $^{1}$} & \multirow[t]{2}{*}{$\begin{array}{c}\text { Time of } \\
\text { application }^{2}\end{array}$} & \multicolumn{2}{|c|}{ Grain yield } \\
\hline & & & & $\mathrm{t} \mathrm{ha}^{-1}$ & $\%$ \\
\hline Untreated check & - & - & - & $4.0 \mathrm{~d}$ & 40 \\
\hline Tembotrione & 88 & None & A & $10.1 \mathrm{a}$ & 100 \\
\hline Tembotrione & 44 & None & A & $9.1 \mathrm{bc}$ & 90 \\
\hline Tembotrione & 22 & None & A & $7.8 \mathrm{c}$ & 77 \\
\hline Tembotrione & 44 & $\mathrm{MSO}+\mathrm{AMN}$ & A & $10.9 \mathrm{a}$ & 108 \\
\hline Tembotrione & 22 & $\mathrm{MSO}+\mathrm{AMN}$ & A & $9.1 \mathrm{bc}$ & 90 \\
\hline Flufenacet + isoxaflutole & $36+7.5$ & None & 0 & $10.2 \mathrm{a}$ & 101 \\
\hline Tembotrione + flufenacet + isoxaflutole & $44+19.2+4.0$ & $\mathrm{MSO}+\mathrm{AMN}$ & A & $10.0 \mathrm{ab}$ & 99 \\
\hline Tembotrione & 44 & $\mathrm{MSO}+\mathrm{AMN}$ & $\mathrm{B} / \mathrm{C}$ & $9.5 \mathrm{ab}$ & 94 \\
\hline Tembotrione & 22 & $\mathrm{MSO}+\mathrm{AMN}$ & $\mathrm{B} / \mathrm{C}$ & $9.7 \mathrm{ab}$ & 96 \\
\hline Tembotrione + flufenacet + isoxaflutole & $22+9.6+2.0$ & $\mathrm{MSO}+\mathrm{AMN}$ & $\mathrm{B} / \mathrm{C}$ & $10.0 \mathrm{ab}$ & 99 \\
\hline
\end{tabular}

${ }^{1}$ MSO: Methylated seed oil at $1.0 \mathrm{~L} \mathrm{ha}^{-1} ; \mathrm{AMN}$ : ammonium nitrate at $2.0 \mathrm{~kg} \mathrm{ha}^{-1}$.

${ }^{2} 0$ : Maize BBCH 00 (dry seed); A: maize BBCH 13-15 (3-5 unfolded leaves); B: maize BBCH 12-13 (3-3 unfolded leaves); C: maize BBCH 16-18 (6-8 unfolded leaves).

Means within a columns followed by the same letter are not significantly different according to Tukey's test $(\mathrm{P} \leq 0.05)$. 
$8 \%$, but at $22 \mathrm{~g} \mathrm{ha}^{-1}$ with adjuvants grain yield increase was not as evident. Substantial grain yield increase gave also flufenacet + isoxaflutole applied once without adjuvants even though this herbicide mixture provided an unsatisfactory weed control. Application of reduced rates of tembotrione ( 44 and $22 \mathrm{~g} \mathrm{ha}^{-1}$ ) and especially mixture of tembotrione with flufenacet + isoxaflutole with MSO + AMN adjuvants applied twice provided similar grain yield of maize as from treatments where tembotrione or flufenacet + isoxaflutole herbicides were applied only once at recommended rates $\left(9.5,9.7\right.$, and $10.0 \mathrm{t} \mathrm{ha}^{-1}$, respectively). In previous study with various herbicides Woznica and Idziak (2010) indicate that split application of herbicides contributed to the increase in yield much stronger than a single treatment.

\section{CONCLUSIONS}

The results of this study confirm the potential of emulsified methylated seed oil, ammonium nitrate, and split application of herbicides, as an effective solution that can be exploited in weed management. Addition of adjuvant, and appropriate treatment time can increase herbicide activity, especially to hard-to-control weed species. It seems that the total elimination of weeds from the maize field is not a prerequisite for confirming the efficacy of the treatment, because as indicate the results of the study, some weeds may exist after treatment, if their competition with maize plant is very low.

\section{LITERATURE CITED}

Armel, G.R., H.P. Wilson, R.J. Richardson, and T.E. Hines. 2003. Mesotrione alone and in mixtures with glyphosate in glyphosateresistant corn (Zea mays). Weed Technology 17:680-685.

Bailey, K.L., S. Falk, J. Derby, M. Melzer, and G.J. Boland. 2013. The effect of fertilizers on the efficacy of the bioherbicide, Phoma macrostoma, to control dandelions in turfgrass. Biological Control 65:147-151

Bystro, J.P., N. de Leon, and W.F. Tracy. 2012. Analysis of traits related to weed competitiveness in sweet corn (Zea mays L.) Sustainability 4:543-560.

Costa, N.V., D. Martins, R.A. Rodella, and L.D.N. de Camargo da Costa. 2005. Droplet deposition during spray and leaf $\mathrm{pH}$ in aquatic weed control. Scientia Agricola 62:227-234

Dewey, S.A., and K.A. Andersen. 2004. Distinct roles of surveys, inventories, and monitoring in adaptive weed management. Weed Technology 18:1449-1452.

Evans, S.P., S.Z. Knezevic, J.L. Lindquist, C.A. Shapiro, and E.E. Blankenship. 2003. Nitrogen application influence the critical period for weed control in corn. Weed Science 51:408-417.

Gatzweiler, E., H. Krahmer, E. Hacker, M. Hills, K. Trabold, and G. Bonfig-Picard. 2012. Weed spectrum and selectivity of tembotrione under varying environmental conditions. $25^{\text {th }}$ German Conference on Weed Biology and Weed Control, Braunschweig, Germany. 13-15 March. Julius-Kuhn-Archiv 434:385.

Ghanizadeh, H., S. Lorzadeh, and N. Ariannia. 2010. Critical period for weed control in corn in the south-west of Iran. Asian Journal of Agricultural Research 4(2):80-86.

Golebiowska, H., and H. Rola. 2003. The influence of weather conditions on selectivity of sulfonylurea herbicides to the selected maize varieties. Journal of Plant Protection Research 43:219-224.
Isik, D., H. Mannan, B. Bukan, A. Oz, and M. Ngauajiro. 2006. The critical period for weed control in corn in Turkey. Weed Technology 20:867-872.

Idziak, R., W. Skrzypczak, H. Waligora, and Z. Woznica. 2013. The effect of mesotrione applied with adjuvants on weed control efficacy and forage sorghum tolerance. Turkish Journal of Agriculture and Forestry 37:265-270.

Idziak, R., and Z. Woznica 2013. Effect of nitrogen fertilizers and oil adjuvants on nicosulfuron efficacy. Turkish Journal of Field Crops 18:174-178.

Idziak, R., and Z. Woznica. 2009. Effectiveness evaluation of oil and mineral adjuvants in mixtures of herbicides Callisto $100 \mathrm{SC}$ and Maister 310 WG applied in maize protection. Acta Scientiarum Polonorum, Agricultura 8:17-26.

Keller, M., G. Gantoli, A. Kipp, C. Gutjahr, and R. Gerhards. 2012. The effect and dynamics of weed competition on maize in Germany and Benin. 25 ${ }^{\text {th }}$ German Conference on Weed Biology and Weed Control, Braunschweig, Germany. 13-15 March 2012. Julius-Kuhn-Archiv 434:289-299.

Kierzek, R., K. Miklaszewska, R. Krawczyk, and K. Matysiak. 2011. Effect of the foliage application date of herbicide mixtures on weed control in maize. Progress in Plant Protection 51:1836-1841.

Lubbers, M.D., P.W. Stahlman, and K. Al-Khatib. 2007. Fluroxypyr efficacy is affected by relative humidity and soil moisture. Weed Science 55:206-263.

Matuszkiewicz, W. 2012. Przewodnik do oznaczania zbiorowisk roslinnych Polski. 540 p. PWN, Warsaw, Poland

Mphundi, P., and J. Allemann. 2010. Effect of temperature on maize sensitivity to acetochlor. p. 213-218. In Adipala, E., G. Tusiime, and J.G. Majaliwa Mwanjololo (eds.) Proceedings of the Second RUFORUM Biennial Regional Conference on Building Capacity for Food Security in Africa, Entebbe, Uganda. 20-24 September 2010. RUFORUM Working Document Series nr 5. Regional Universities Forum for Capacity Building in Agriculture (RUFORUM), Kampala, Uganda.

Naeem, M., Z.A. Cheema, A.H. Ahmad, A. Wahid, M. Kamaran, and M. Arif. 2012. Weed dynamics in wheat-canola intercropping systems. Chilean Journal of Agricultural Research 72:434-439.

Price, A.J., K.S. Balkcom, S.A. Culpepper, J.A. Kelton, R.L. Nichols, and H. Schomberg. 2011. Glyphosate-resistant Palmer amaranth: A threat to conservation tillage. Journal of Soil and Water Conservation 66:265-275.

Ramsdale, B.K., and C.G. Messersmith. 2002. Low-rate splitapplied herbicide treatments for wild oat (Avena fatua) control in wheat (Triticum aestivum). Weed Technology 16:149-155.

Ramsey, R.J.L. 2003. Effect of humidity on the absorption and efficacy of glufosinate ammonium in wild oat (Avena fatua L.) 113 p. PhD thesis. University of Guelph, Faculty of Graduate Studies, Guelph, Ontario, Canada.

Ramsey, R.J.L., G.R. Stephenson, and J.C. Hall. 2005. A review of the effects of humidity, humectants, and surfactant composition on the absorption and efficacy of highly water-soluble herbicides. Pesticide Biochemistry and Physiology 82:162-175.

SgP. 2011. Systematyka gleb Polski. Soil Science Annual (Roczniki Gleboznawcze) 62(3):5-142.

Snarska, K., and R. Konecki. 2010. Assessment of effectiveness of selected herbicides used for limiting weeds in sorghum. Progress in Plant Protection 50:1405-1409.

Sulewska, H., W. Koziara, K. Smiatacz, G. Szymanska, and K. Panasiewicz. 2012. Efficacy of selected herbicides in weed control of maize. Fragmenta Agronomica 29:144-151.

Tański, M., and R. Idziak. 2009. Influence of weed control regulation on herbicide efficacy and grain yield of maize. Progress in Plant Protection 49:349-352.

Vahedi, A., Z. Bakhshi, R. Fakhari, and H.R. Vahidipour. 2013. Evaluation of competitiveness of corn and pigweed in nitrogen levels under pigweed densities by corn yield converse relations. International Journal of Agriculture and Crop Sciences 5:14421444. 
Waligora, H., P. Szulc, and W. Skrzypczak. 2008a. Weed control effectiveness in sugar maize cultivation with isoxaflutol + flufenacet mixture. Nauka Przyroda Technologia 2(3):1-6.

Waligora, H., P. Szulc, and W. Skrzypczak. 2008b. Effectiveness of chemical weed control in sugar maize cultivation without triazyne. Acta Scientiarum Polonorum, Agricultura 7:111-118.

Williams, B.J., and R.G. Harvey. 2000. Effect of nicosulfuron timing on wild-proso millet (Panicum miliaceum) control in sweet corn (Zea mays). Weed Technology 14:377-382.

Woznica, Z., and R. Idziak. 2010. Influence of herbicide application timings, rates and adjuvant type on weed control and yield of maize grown for forage. Acta Scientiarum Polonorum, Agricultura 9(4):77-84
Young, B.G., R.K. Zollinger, and M.L. Bernards. 2007. Variability of tembotrione efficacy as influenced by commercial adjuvant products. North Central Weed Science Society Proceedings 62:141.

Zollinger, R.K. 2011. North Dakota weed control guide. 135 p. North Dakota State University (NDSU) Extension Service, Fargo, North Dakota, USA.

Meier, U. (ed.) 2001. Growth stages of mono-and dicotyledonous plants. BBCH Monograph. Federal Biological Research Centre for Agriculture and Forestry (BBA), Braunschweig, Germany. Available at http://www.bba.de/veroeff/bbch/bbcheng.pdf (accessed September 2013). 